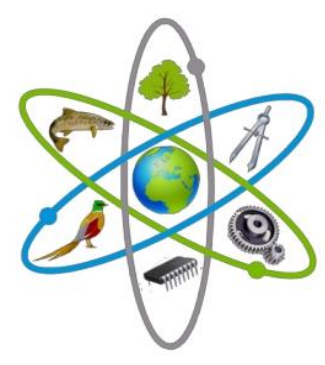

Natural and Engineering Sciences

Volume 1, No. 2, 1-14,2016

\title{
The Effects of Season and Sex on the Nutritional Quality of Muscle Types of Blue Crab Callinectes sapidus and Swimming Crab Portunus segnis
}

\author{
Deniz AYAS ${ }^{1,2}$ \\ ${ }^{1}$ Department of Seafood and Processing Technology, Faculty of Fisheries, Mersin University, \\ Mersin, Turkey \\ ${ }^{2}$ Ekosfer Environmental Consulting Limited, Mersin Technology Development Zone \\ (Technoscope), Mersin, Turkey
}

\begin{abstract}
The effects of season and sex on the nutritional quality of muscle types (lump crab meatLCM, claw crab meat-CCM) of swimming crab (Portunus segnis) and blue crab (Callinectes sapidus) were investigated. Carapace width, carapace length and total weight of both crab species were measured. High protein content in spring and low protein content in autumn were observed for both crab species. The levels of lipid content of both crab species were found to be similar. Higher lipid contents in spring and winter, lower lipid contents in summer and autumn for both sexes were found. Although both crab species contain small amounts of fat, they are good sources of n-3 PUFA content (especially EPA and DHA) for all seasons regardless of sex and muscle types.
\end{abstract}

Keywords:

Crabs, nutritional quality, fatty acids, EPA, DHA

Article history:

Received 15 April 2016, Accepted 01 May 2016, Available online 10 May 2016

\section{Introduction}

Swimming crab (Portunus segnis) and blue crab (Callinectes sapidus) belong to Portunidea family. Swimming crab is an Indio-Pacific species which came to the Mediterranean waters after the opening of Suez Canal. The blue crab is mainly distributed North-West American lagoons and coasts. Blue crabs are commonly distributed in the Northeastern Mediterranean shores in Turkey. Portunid crabs are important species of big sea crabs consumed both in the world and our country. Portunid crabs are the most important members of the sea food chain

\footnotetext{
*Corresponding Author: Deniz Ayas, e-mail: ayasdeniz@gmail.com
} 
as while they feed on detritus, fish, alga, plant, cephalopods, decapods and annelids, they serve as preys to mammals, birds and fishes (Hall et al., 2006). Furthermore, Portunid crabs play an important role in the carriage of fatty acids to mammals. According to Fishstat plus report (2010), the annual catch of crabs which consisted of mainly Portunid crabs in 2008 was 1.319.953 tones. In Turkey, 55 and 95 tons of swimming crabs were caught in 2003 and 2007 whereas 17 and 77 tons of blue crab were caught in 2008 and 2009, respectively.

There are three n-3 long chain polyunsaturated fatty acids (LC-PUFAs) commonly found in food, especially seafood. Evidence of health benefits is associated with the marine sourced n-3 LC-PUFAs: eicosapentaenoic acid (EPA) and docosahexaenoic acid (DHA). Alpha-linoleic acid (ALA) is a non-marine sourced n-3 LC-PUFA and occurs in seed crops such as canola, soybean oils, walnuts (McManus et al., 2011). Humans can synthesize portions of their requirements for elongated n-3 fatty acids from the short-chain precursor ALA (Burdge \& Calder, 2005). However, synthesis of EPA and DHA from ALA is generally not sufficient to meet dietary requirements (Brenna et al., 2009). As EPA and DHA are essential nutrients, dietary intake from fish and shellfish is necessary for adequate levels. Marine based n-3 LC-PUFAs has a greater positive impact on health than non-marine sourced n-3 LC-PUFAs. Wang et al. (2006) reviewed that the efficacy of n-3 LC-PUFAs in primary and secondary prevention studies on cardiovascular disease revealed that consumption of n-3 LC-PUFAs from fish or fish oil consumption, but not consumption of ALA, improved rates of all-cause mortality, cardiac and sudden death. Fish and shellfish are important food resources globally.

Although the nutritional composition of different species of crabs has been characterized (Moustafa et al., 1987; Reddy et al., 1991; Siddiquie et al., 1987; Chung, 1999; Gökoğlu \&Yerlikaya, 2003; Skonberg \& Perkins, 2002; Naczk et al., 2004), shellfish vary widely in their nutrient content (Ackman \& McLeod, 1988; King et al., 1990). Researchers have also reported differences in proximate and fatty acid and metal content of two crab species (C. sapidus and P. pelagicus) (Gökoğlu \& Yerlikaya, 2003). In addition, Kuley et al. (2008) also compared the fatty acid and proximate compositions of the body and claw of male and female blue crabs (Callinectes sapidus) from different regions of the Mediterranean coast.

The aim of this study was to investigate the effects of season and sex on the nutritional quality of muscle types (lump crab meat-LCM, claw crab meat-CCM) of Callinectes sapidus and Portunus segnis. Information on the nutrient composition is needed to facilitate the processing, utilization, and marketing of these crab species because they are abundant in Mediterranean Sea.

\section{Material and Method}

\section{Sample preparation}

After catching crabs by trawl in spring, autumn and winter, summer, they were immediately iced and transported to the laboratory in ice. Each crab species (30 individuals for each sex and each season) were caught in the eastern Mediterranean Sea. The species of crab were identified and their carapace width, carapace length and total weight were measured (Table 1). Muscle tissues (LCM-lump crab meat, CCM- claw crab meat) of each sex were taken out by hand. All assays were conducted on triplicate samples of the homogenates. Chemical composition analyses were carried out on these muscle tissue samples. For this study, total 480 individuals were used. 


\section{Proximate analyses}

The following chemical constituents were determined on samples of all muscles according to the official methods of analysis of the AOAC (2003): moisture content by oven drying a ca. 2$\mathrm{g}$ test sample at $102{ }^{\circ} \mathrm{C}$ to a constant weight (950.46B, see p. 39.1.02); ash content by igniting a $c a$. 3-5-g test sample in a muffle furnace at $550^{\circ} \mathrm{C}$ until light grey ash results $(920.153$, see p. 39.1.09); crude protein content by the classical macro-Kjeldahl method (981.10, see p. 39.1.19); and lipid (crude) content by Bligh \& Dyer (1959) using chloroform/methanol extraction.

\section{Fatty acid methyl ester analyses (FAME)}

Lipid extraction was made according to the Bligh \& Dyer method (1959). Methyl esters were prepared by transmethylation using $2 \mathrm{M} \mathrm{KOH}$ in methanol and n-heptane, according to the method described by Ichibara et al. (1996), with minor modification. Extracted oil (10 mg) was dissolved in $2 \mathrm{ml} \mathrm{n}$-heptane, followed by $4 \mathrm{ml}$ of $2 \mathrm{M}$ methanolic $\mathrm{KOH}$. The tube was then vortexed for $2 \mathrm{~min}$ at room temperature. After centrifugation at $4000 \mathrm{rpm}$ for $10 \mathrm{~min}$, the $n$-heptane layer was taken for GC analysis.

\section{Gas chromatographic condition}

The fatty acid composition was analyzed by the GC Clarus 500 with autosampler (Perkin Elmer, Shelton, CT, USA) equipped with a flame ionization detector and a fused silica capillary SGE column (30 m $0.32 \mathrm{~mm}$, ID $0.25 \mathrm{~mm}$, BP20 $0.25 \mathrm{UM}$; SGE Analitic Science Pty Ltd, Victoria, Australia). The oven temperature was $140{ }^{\circ} \mathrm{C}$, held for $5 \mathrm{~min}$, raised to 200 ${ }^{\circ} \mathrm{C}$ at a rate of $4{ }^{\circ} \mathrm{C} / \mathrm{min}$ and to $220^{\circ} \mathrm{C}$ at a rate of $1{ }^{\circ} \mathrm{C} / \mathrm{min}$, while the injector and the detector temperature were set at $220{ }^{\circ} \mathrm{C}$ and $280{ }^{\circ} \mathrm{C}$, respectively. The sample size was $1 \mu \mathrm{L}$ and the carrier gas helium was controlled at 16 ps. The split used was 1:100. Fatty acids were identified by comparing the retention times of fatty acid methyl esters with a standard 37component fatty acid methyl ester mixture (catalog no 18919; Supelco). Triplicate GC analyses were performed and the results were expressed in GC area $\%$ as the mean value \pm standard deviation.

\section{Statistical analysis}

For data analysis, each sampling season was subjected to one-way analysis of variance, at the $5 \%$ confidence level, using the Duncan multiple range test (IBM SPPS Statistics Version 22)

\section{Results}

The mean carapace width (CW) was 112.0-175.0 mm for swimming crabs (Table 1). Average carapace widths of females and males' blue crabs were $125.0 \mathrm{~mm}$ and $185.0 \mathrm{~mm}$, respectively (Table 1).

\section{Proximate composition}

Protein, lipid, ash, moisture and muscle composition of both crab species are given in Table 2 . The protein contents of blue crab were in the range of $21.4-24.3 \%, 19.2-23.3 \%, 16.6-20.2 \%$, $19.2-21.8 \%$ in spring, summer, autumn and winter respectively (Table 2). The lowest protein content of blue crab for both sex was obtained from autumn whereas spring gave the highest protein content $(\mathrm{P}<0.05)$. Seasonal protein contents of both males and females of swimming crab were in the range of $21.7 \%-23.5 \%, 19.1 \%-21.4 \%, 15.4 \%-18.0 \%, 16.2 \%-20.0 \%$ in spring, 
summer, autumn and winter, respectively (Table 2). The highest protein content of swimming crab for both sex was obtained from spring $(\mathrm{P}<0.05)$. In addition, the protein levels of swimming crab in spring and summer were higher than those in autumn and winter $(\mathrm{P}<0.05)$.

Table1. Morphological measurements of the big sea crabs.

\begin{tabular}{|c|c|c|c|c|c|c|c|c|c|}
\hline Season & Species & $\mathrm{N}$ & $\begin{array}{l}\mathrm{CL}(\mathrm{mm}) \\
\bar{X} \pm \mathrm{S}_{\overline{\mathrm{X}}}\end{array}$ & $\begin{array}{l}\mathrm{CL} \\
(\mathrm{mm}) \\
(\mathrm{min}- \\
\max )\end{array}$ & $\begin{array}{l}\mathrm{CW}(\mathrm{mm}) \\
\bar{X} \pm \mathrm{S}_{\overline{\mathrm{X}}}\end{array}$ & $\begin{array}{l}\mathrm{CW} \\
(\mathrm{mm}) \\
(\min - \\
\max )\end{array}$ & $\begin{array}{l}\text { weight (g) } \\
\bar{X} \pm S_{\bar{X}}\end{array}$ & $\begin{array}{l}\text { weight }(\mathrm{g}) \\
(\min -\max )\end{array}$ & Sex \\
\hline \multirow{4}{*}{$\begin{array}{l}\text { Spring } \\
\text { (April) }\end{array}$} & $\begin{array}{l}C . \\
\text { sapidus }\end{array}$ & 30 & $71.27 \pm 4.13^{\mathrm{a}}$ & $\begin{array}{l}63.0- \\
80.0\end{array}$ & $154.30 \pm 9.40^{\mathrm{a}}$ & $\begin{array}{l}129.5- \\
170.0\end{array}$ & $171.67 \pm 25.77^{a}$ & $\begin{array}{l}\text { 115.27- } \\
225.92\end{array}$ & q \\
\hline & $\begin{array}{l}\text { C. } \\
\text { sapidus }\end{array}$ & 30 & $74.17 \pm 3.79^{a}$ & $\begin{array}{l}68.0- \\
80.5\end{array}$ & $151.65 \pm 8.64^{a}$ & $\begin{array}{l}128.0- \\
163.0\end{array}$ & $191.11 \pm 25.58^{a}$ & $\begin{array}{l}154.03- \\
237.93\end{array}$ & $\hat{\sigma}$ \\
\hline & P. segnis & 30 & $71.72 \pm 5.60^{\mathrm{a}}$ & $\begin{array}{l}65.0- \\
83.0\end{array}$ & $148.93 \pm 12.36^{\mathrm{a}}$ & $\begin{array}{l}130.5- \\
175.0\end{array}$ & $255.80 \pm 57.80^{\mathrm{a}}$ & $\begin{array}{l}160.33- \\
390.83\end{array}$ & o \\
\hline & P. segnis & 30 & $65.88 \pm 6.10^{\mathrm{a}}$ & $\begin{array}{l}54.0- \\
76.5\end{array}$ & $131.68 \pm 10.35^{\mathrm{a}}$ & $\begin{array}{l}112.0- \\
145.0\end{array}$ & $138.48 \pm 22.04^{\mathrm{a}}$ & $\begin{array}{l}107.37- \\
177.59\end{array}$ & $\hat{\sigma}$ \\
\hline \multirow{4}{*}{$\begin{array}{l}\text { Summer } \\
\text { (July) }\end{array}$} & $\begin{array}{l}\text { C. } \\
\text { sapidus }\end{array}$ & 30 & $69.83 \pm 2.53^{a}$ & $\begin{array}{l}66.0- \\
75.0\end{array}$ & $153.37 \pm 6.49^{a}$ & $\begin{array}{l}141.5- \\
162.0\end{array}$ & $164.86 \pm 16.12^{a}$ & $\begin{array}{l}140.16- \\
195.56\end{array}$ & q \\
\hline & $\begin{array}{l}\text { C. } \\
\text { sapidus }\end{array}$ & 30 & $73.40 \pm 4.19^{\mathrm{a}}$ & $\begin{array}{l}64.5- \\
79.5\end{array}$ & $149.90 \pm 12.31^{\mathrm{a}}$ & $\begin{array}{l}125.0- \\
165.0\end{array}$ & $233.01 \pm 33.21^{\mathrm{a}}$ & $\begin{array}{l}165.90- \\
290.78\end{array}$ & $\hat{\sigma}$ \\
\hline & P. segnis & 30 & $70.37 \pm 5.35^{\mathrm{a}}$ & $\begin{array}{l}62.0- \\
80.5\end{array}$ & $140.70 \pm 9.40^{\mathrm{a}}$ & $\begin{array}{l}124.0- \\
155.5\end{array}$ & $197.66 \pm 49.46^{\mathrm{a}}$ & $\begin{array}{l}130.28- \\
308.75\end{array}$ & 우 \\
\hline & P. segnis & 30 & $69.23 \pm 4.16^{\mathrm{a}}$ & $\begin{array}{l}62.5- \\
76.0\end{array}$ & $137.00 \pm 6.25^{\mathrm{a}}$ & $\begin{array}{l}125.0- \\
147.0\end{array}$ & $206.38 \pm 30.42^{\mathrm{a}}$ & $\begin{array}{l}171.20- \\
290.10\end{array}$ & $\hat{\sigma}$ \\
\hline \multirow{4}{*}{$\begin{array}{l}\text { Autumn } \\
\text { (October) }\end{array}$} & $\begin{array}{l}\text { C. } \\
\text { sapidus }\end{array}$ & 30 & $68.97 \pm 2.58^{a}$ & $\begin{array}{l}65.0- \\
72.0\end{array}$ & $149.87 \pm 4.32^{\mathrm{a}}$ & $\begin{array}{l}145.0- \\
156.0\end{array}$ & $160.65 \pm 12.51^{\mathrm{a}}$ & $\begin{array}{l}140.07- \\
175.01\end{array}$ & ㅇ \\
\hline & $\begin{array}{l}C . \\
\text { sapidus }\end{array}$ & 30 & $77.33 \pm 3.64^{a}$ & $\begin{array}{l}\text { 73.0- } \\
82.0\end{array}$ & $153.42 \pm 9.43^{a}$ & $\begin{array}{l}145.0- \\
169.0\end{array}$ & $262.06 \pm 39.67^{a}$ & $\begin{array}{l}\text { 205.11- } \\
321.85\end{array}$ & $\hat{\sigma}$ \\
\hline & P. segnis & 30 & $69.70 \pm 7.06^{\mathrm{a}}$ & $\begin{array}{l}61.5- \\
82.5\end{array}$ & $133.75 \pm 12.78^{a}$ & $\begin{array}{l}122.0- \\
160.0\end{array}$ & $170.48 \pm 47.61^{\mathrm{a}}$ & $\begin{array}{l}132.06- \\
268.64\end{array}$ & q \\
\hline & P. segnis & 30 & $70.92 \pm 3.06^{\mathrm{a}}$ & $\begin{array}{l}66.0- \\
75.0\end{array}$ & $138.33 \pm 6.01^{\mathrm{a}}$ & $\begin{array}{l}131.0- \\
147.0\end{array}$ & $215.63 \pm 18.37^{\mathrm{a}}$ & $\begin{array}{l}201.90- \\
253.40\end{array}$ & $\widehat{\sigma}$ \\
\hline \multirow{4}{*}{$\begin{array}{l}\text { Winter } \\
\text { (December) }\end{array}$} & $\begin{array}{l}C . \\
\text { sapidus }\end{array}$ & 30 & $71.45 \pm 4.37^{a}$ & $\begin{array}{l}67.0- \\
79.0\end{array}$ & $153.70 \pm 8.91^{\mathrm{a}}$ & $\begin{array}{l}142.0- \\
168.0\end{array}$ & $168.89 \pm 20.29^{a}$ & $\begin{array}{l}145.93- \\
203.09\end{array}$ & q \\
\hline & $\begin{array}{l}\text { C. } \\
\text { sapidus }\end{array}$ & 30 & $79.23 \pm 4.29^{\mathrm{a}}$ & $\begin{array}{l}\text { 73.5- } \\
90.5\end{array}$ & $164.58 \pm 12.03^{a}$ & $\begin{array}{l}145.5- \\
185.0\end{array}$ & $312.68 \pm 44.68^{\mathrm{a}}$ & $\begin{array}{l}\text { 247.19- } \\
386.10\end{array}$ & $\sigma^{\pi}$ \\
\hline & P. segnis & 30 & $73.75 \pm 4.04^{\mathrm{a}}$ & $\begin{array}{l}68.5- \\
81.5\end{array}$ & $143.65 \pm 6.52^{\mathrm{a}}$ & $\begin{array}{l}137.0- \\
156.0\end{array}$ & $203.78 \pm 30.73^{a}$ & $\begin{array}{l}166.56- \\
262.73\end{array}$ & q \\
\hline & P. segnis & 30 & $69.10 \pm 3.76^{\mathrm{a}}$ & $\begin{array}{l}64.0- \\
74.5\end{array}$ & $137.07 \pm 6.02^{\mathrm{a}}$ & $\begin{array}{l}130.5- \\
151.0\end{array}$ & $224.05 \pm 32.45^{\mathrm{a}}$ & $\begin{array}{l}177.11- \\
277.47\end{array}$ & $\sigma^{\pi}$ \\
\hline
\end{tabular}

Values in same column with different letters are significantly different $(\mathrm{P}<0.05) \cdot \overline{\mathrm{X}} \pm \mathrm{S}_{\overline{\mathrm{X}}}:$ Standard deviation

\section{Fatty acid profiles}

Saturated fatty acids (SFA), monounsaturated fatty acids (MUFAs), polyunsaturated fatty acids (PUFAs) of lump and claw of males and females both crab species are presented in Tables 3, 4 and 5 respectively. The highest proportions of fatty acids found in both crab species were myristic acid (C14:0), palmitic acid (C16:0), heptadecanoic acid (C17:0), stearic acid (C18:0), arachidic acid (C20:0), palmitoleic acid (C16:1), heptadecenoic acid (C17:1), oleic acid (C18:1n-9), octadecenoic acid (C18:1n-7), linoleic acid (C18:2n-6), arachidonic acid (C20:4 n-6), cis-5,8,11,14, 17-eicosapentaenoic acid (EPA, C20:5 n-3) and cis4,7,10,13,16,19-docosahexaenoic acid (DHA, C22:6n-3). These results are in agreement with those in previous studies (Kuley et al., 2008; Ayas \& Ozogul, 2011 a,b).

Significant differences $(\mathrm{P}<0.05)$ in SFA contents were observed in terms of sex, season and muscle types (Table 3). SFA levels of LCM of female blue crab (C. sapidus) were found to be $25.24 \%$ in spring, $28.25 \%$ in summer, $27.41 \%$ in autumn, and $21.63 \%$ in winter whereas its levels in CCM were $23.65 \%, 27.02 \%, 28 \%$ and $22.09 \%$, respectively. The highest levels of SFA were obtained from LCM in summer (28.25\%) and from CCM (28.0\%) in 
autumn. However, SFA levels of LCM of male blue crab were $24.74 \%, 28.63 \%, 26.04 \%$ and $24.82 \%$ while its levels in CCM were $23 \%, 27.38 \%, 25.85 \%$ and $23.64 \%$ in spring, summer, autumn and winter, respectively. LCM and CCM in summer gave the highest SFA content in male blue crabs. As for swimming crab (P. segnis), SFA levels of LCM of females were found to be $23.88 \%$ in spring, $27.51 \%$ in summer, $26.89 \%$ in autumn, and $25.18 \%$ in winter. SFA levels in CCM of females were $23.63 \%$ in spring, $26.68 \%$, in summer, $27.11 \%$ in autumn and $23.37 \%$ in winter. SFA levels of LCM of males were found to be $27.48 \%$ in spring, $27.72 \%$ in summer, $25.88 \%$ in autumn, and $24.79 \%$ in winter whereas its levels in CCM were $23.89 \%, 24.59 \%, 27.10 \%$ and $23.90 \%$, respectively. The dominant SFAs were palmitic acid (16:0), ranging from $10.61 \%$ to $15.41 \%$ and stearic acid (18:0), ranging from $7.15 \%$ to $11.81 \%$.

Table 2. Proximate composition of the big sea crabs (\%).

\begin{tabular}{|c|c|c|c|c|c|c|c|c|}
\hline Season & Species & Sex & $\mathrm{N}$ & $\begin{array}{l}\text { Protein } \\
\bar{X} \pm S_{X}\end{array}$ & $\begin{array}{l}\text { Lipid } \\
\bar{X} \pm S_{X}\end{array}$ & $\begin{array}{l}\text { Ash } \\
\bar{X} \pm S_{x}\end{array}$ & $\begin{array}{l}\text { Moisture } \\
\bar{X} \pm S_{X}\end{array}$ & Muscle \\
\hline \multirow{8}{*}{$\begin{array}{l}\text { Spring } \\
\text { (April) }\end{array}$} & \multirow{3}{*}{ C. sapidus } & $q$ & 30 & $21.64 \pm 0.30^{\mathrm{kl}}$ & $1.24 \pm 0.03^{\mathrm{gh}}$ & $2.18 \pm 0.23^{f}$ & $74.33 \pm 0.20^{c}$ & LCM \\
\hline & & & 30 & $24.33 \pm 0.16^{p}$ & $0.80 \pm 0.01^{d}$ & $2.24 \pm 0.15^{f}$ & $72.48 \pm 0.37^{\mathrm{a}}$ & CCM \\
\hline & & $\sigma^{\pi}$ & 30 & $21.41 \pm 0.13^{k}$ & $1.22 \pm 0.04^{\mathrm{gh}}$ & $2.25 \pm 0.05^{f}$ & $74.98 \pm 0.09^{d}$ & $\mathrm{LCM}$ \\
\hline & \multirow{5}{*}{ P. segnis } & & 30 & $22.25 \pm 0.09^{\mathrm{m}}$ & $0.92 \pm 0.02^{\mathrm{ef}}$ & $2.07 \pm 0.03^{e}$ & $74.65 \pm 0.26^{c}$ & CCM \\
\hline & & 우 & 30 & $23.25 \pm 0.18^{\mathrm{n}}$ & $1.15 \pm 0.04^{\mathrm{g}}$ & $2.14 \pm 0.05^{\mathrm{f}}$ & $73.02 \pm 0.05^{\mathrm{a}}$ & $\mathrm{LCM}$ \\
\hline & & & 30 & $23.53 \pm 0.06^{\circ}$ & $0.84 \pm 0.01^{\mathrm{e}}$ & $2.23 \pm 0.05^{\mathrm{f}}$ & $73.08 \pm 0.09^{\mathrm{a}}$ & CCM \\
\hline & & $\hat{\sigma}$ & 30 & $22.03 \pm 0.41^{\mathrm{klm}}$ & $1.39 \pm 0.03^{\mathrm{h}}$ & $2.12 \pm 0.04^{\mathrm{ef}}$ & $74.24 \pm 0.22^{\mathrm{c}}$ & $\mathrm{LCM}$ \\
\hline & & & 30 & $21.67 \pm 0.18^{\mathrm{kl}}$ & $0.88 \pm 0.06^{\mathrm{ef}}$ & $2.34 \pm 0.08^{\mathrm{g}}$ & $74.84 \pm 0.10^{\mathrm{cd}}$ & CCM \\
\hline \multirow{8}{*}{$\begin{array}{l}\text { Summer } \\
\text { (July) }\end{array}$} & \multirow{3}{*}{ C. sapidus } & $q$ & 30 & $20.79 \pm 0.20^{h}$ & $0.86 \pm 0.01^{e}$ & $2.09 \pm 0.02^{\text {ef }}$ & $76.01 \pm 0.08^{g}$ & LCM \\
\hline & & & 30 & $23.32 \pm 0.04^{\mathrm{n}}$ & $0.81 \pm 0.01^{\mathrm{d}}$ & $2.35 \pm 0.04^{\mathrm{g}}$ & $73.36 \pm 0.04^{b}$ & CCM \\
\hline & & $\hat{\sigma}$ & 30 & $19.19 \pm 0.11^{\mathrm{f}}$ & $1.01 \pm 0.05^{\mathrm{f}}$ & $2.33 \pm 0.03^{g}$ & $77.36 \pm 0.04^{1}$ & LCM \\
\hline & \multirow{5}{*}{ P. segnis } & & 30 & $20.25 \pm 0.12^{\mathrm{g}}$ & $0.69 \pm 0.01^{c}$ & $2.48 \pm 0.03^{h}$ & $76.46 \pm 0.04^{h}$ & CCM \\
\hline & & q & 30 & $21.26 \pm 0.15^{\mathrm{k}}$ & $0.84 \pm 0.04^{\mathrm{e}}$ & $2.19 \pm 0.03^{\mathrm{f}}$ & $75.57 \pm 0.03^{\mathrm{e}}$ & $\mathrm{LCM}$ \\
\hline & & & 30 & $21.44 \pm 0.07^{\mathrm{k}}$ & $0.74 \pm 0.02^{c}$ & $2.54 \pm 0.01^{\mathrm{hk}}$ & $74.86 \pm 0.07^{\mathrm{cd}}$ & CCM \\
\hline & & $\hat{\sigma}$ & 30 & $20.69 \pm 0.12^{\mathrm{h}}$ & $0.85 \pm 0.01^{\mathrm{e}}$ & $2.33 \pm 0.01^{\mathrm{g}}$ & $75.85 \pm 0.03^{\mathrm{f}}$ & LCM \\
\hline & & & 30 & $19.09 \pm 0.07^{\mathrm{f}}$ & $0.65 \pm 0.02^{\mathrm{b}}$ & $2.56 \pm 0.15^{\mathrm{hk}}$ & $77.35 \pm 0.08^{1}$ & $\mathrm{CCM}$ \\
\hline \multirow{8}{*}{$\begin{array}{l}\text { Autumn } \\
\text { (October) }\end{array}$} & \multirow{4}{*}{ C. sapidus } & $q$ & 30 & $16.61 \pm 0.20^{c}$ & $0.89 \pm 0.06^{\mathrm{ef}}$ & $1.53 \pm 0.06^{\mathrm{a}}$ & $80.83 \pm 0.07^{p}$ & LCM \\
\hline & & & 30 & $20.17 \pm 0.08^{\mathrm{g}}$ & $0.63 \pm 0.01^{b}$ & $2.06 \pm 0.05^{\mathrm{e}}$ & $76.73 \pm 0.08^{k}$ & $\mathrm{CCM}$ \\
\hline & & $\hat{\sigma}$ & 30 & $19.48 \pm 0.25^{\mathrm{f}}$ & $0.98 \pm 0.04^{f}$ & $1.72 \pm 0.02^{b}$ & $77.64 \pm 0.08^{\mathrm{m}}$ & LCM \\
\hline & & & 30 & $17.00 \pm 0.16^{c}$ & $0.59 \pm 0.01^{\mathrm{a}}$ & $2.13 \pm 0.01^{\mathrm{f}}$ & $79.74 \pm 0.23^{\circ}$ & CCM \\
\hline & \multirow{4}{*}{ P. segnis } & 우 & 30 & $18.02 \pm 0.06^{\mathrm{e}}$ & $0.86 \pm 0.02^{\mathrm{e}}$ & $2.03 \pm 0.03^{\mathrm{e}}$ & $78.52 \pm 0.31^{\mathrm{mn}}$ & LCM \\
\hline & & & 30 & $17.42 \pm 0.09^{\mathrm{d}}$ & $0.64 \pm 0.01^{\mathrm{b}}$ & $2.33 \pm 0.01^{\mathrm{g}}$ & $79.28 \pm 0.15^{\mathrm{n}}$ & CCM \\
\hline & & $\hat{\sigma}$ & 30 & $16.80 \pm 0.01^{\mathrm{c}}$ & $0.85 \pm 0.03^{\mathrm{e}}$ & $1.91 \pm 0.02^{\mathrm{d}}$ & $79.84 \pm 0.11^{\circ}$ & LCM \\
\hline & & & 30 & $15.37 \pm 0.13^{\mathrm{a}}$ & $0.56 \pm 0.02^{\mathrm{a}}$ & $2.66 \pm 0.06^{\mathrm{k}}$ & $81.07 \pm 0.14^{\mathrm{p}}$ & CCM \\
\hline \multirow{8}{*}{$\begin{array}{l}\text { Winter } \\
\text { (December) }\end{array}$} & \multirow{3}{*}{ C. sapidus } & q & 30 & $20.48 \pm 0.04^{g h}$ & $1.21 \pm 0.06^{\mathrm{gh}}$ & $1.76 \pm 0.01^{b}$ & $76.45 \pm 0.39^{h}$ & LCM \\
\hline & & & 30 & $21.80 \pm 0.39^{\mathrm{kl}}$ & $0.84 \pm 0.00^{e}$ & $2.08 \pm 0.10^{\mathrm{ef}}$ & $75.06 \pm 0.04^{d}$ & CCM \\
\hline & & $\hat{\sigma}$ & 30 & $19.20 \pm 0.16^{f}$ & $1.51 \pm 0.03^{k}$ & $1.83 \pm 0.01^{\mathrm{c}}$ & $77.09 \pm 0.27^{\mathrm{kl}}$ & LCM \\
\hline & \multirow{5}{*}{ P. segnis } & & 30 & $21.05 \pm 0.03^{\mathrm{hk}}$ & $1.04 \pm 0.04^{\mathrm{f}}$ & $2.06 \pm 0.03^{e}$ & $75.66 \pm 0.16^{\mathrm{e}}$ & CCM \\
\hline & & q & 30 & $19.54 \pm 0.7^{\mathrm{fg}}$ & $1.49 \pm 0.04^{\mathrm{k}}$ & $2.25 \pm 0.03^{\mathrm{f}}$ & $76.44 \pm 0.13^{\mathrm{h}}$ & LCM \\
\hline & & & 30 & $16.22 \pm 0.04^{\mathrm{b}}$ & $1.02 \pm 0.02^{\mathrm{f}}$ & $2.70 \pm 0.13^{\mathrm{k}}$ & $79.83 \pm 0.07^{\circ}$ & CCM \\
\hline & & $\lambda$ & 30 & $19.99 \pm 0.22^{\mathrm{g}}$ & $1.58 \pm 0.02^{1}$ & $2.17 \pm 0.02^{\mathrm{f}}$ & $76.01 \pm 0.13^{\mathrm{g}}$ & LCM \\
\hline & & & 30 & $17.40 \pm 0.01^{\mathrm{d}}$ & $1.11 \pm 0.00^{\mathrm{g}}$ & $2.41 \pm 0.03^{\mathrm{gh}}$ & $78.89 \pm 0.11^{\mathrm{n}}$ & CCM \\
\hline
\end{tabular}

Value in same column with different letters are significantly different $(\mathrm{P}<0.05) . \quad \overline{\mathrm{X}} \pm \mathrm{S}_{\mathrm{x}}:$ Standard deviation

There were significant differences $(\mathrm{P}<0.05)$ in the level of MUFA between species, sex and also muscle types (Table 4). MUFA levels of LCM of females' blue crab (C. sapidus) were found to be $26.24 \%$ in spring, $25.39 \%$ in summer, $27.48 \%$ in autumn and $22.89 \%$ in winter whereas its levels in CCM were $28.04 \%, 27.33 \%, 31.08 \%, 23.11 \%$, respectively. The highest MUFA levels in both LCM (27.48\%) and CCM (31.08\%) were obtained from autumn 
for female blue crabs. MUFA levels of LCM of male blue crab were $23.22 \%, 22.64 \%$, $25.04 \%$ and $23.84 \%$ while its levels in CCM were $25.86 \%, 25.75 \%, 30.46 \%$ and $27.81 \%$ in spring, summer, autumn and winter, respectively. Similar to females' blue crab, LCM and CCM of male crabs gave the highest MUFA content in autumn. MUFA levels of LCM of females swimming crab (P. segnis) were $23.32 \%, 24.86 \%, 22.26 \%$ and $19.51 \%$ while its levels of CCM of female's swimming crab were found to be $26.67 \%, 26.28 \%, 24.20 \%$, $21.98 \%$ in spring, summer, autumn and winter, respectively. The highest MUFA contents of LCM and CCM of female swimming crab were obtained from summer and spring time. As for male swimming crabs, MUFA contents of LCM were $24.23 \%$ in spring, $19.54 \%$ in summer, $20.35 \%$ in autumn and $19.31 \%$ in winter while MUFA levels of CCM were $24.80 \%$, $22.94 \%, 25 \%$ and $22.89 \%$, respectively. The major monounsaturated fatty acids (MUFA) were palmitoleic acid $(\mathrm{C} 16: 1,3.43-9.10 \%)$, oleic acid $(\mathrm{C} 18: 1 n-9,11.43-20.40 \%)$, and octadecenoic acid (C18:1n-7, 1.62-4.32\%).

Significant differences $(\mathrm{P}<0.05)$ in PUFA contents were observed between sex, seasons and muscle types (Table 5). PUFA levels of LCM of female blue crab (C. sapidus) were found to be $38.94 \%$ in spring, $39.95 \%$ in summer, $39.77 \%$ in autumn, and $41.60 \%$ in winter whereas its levels in CCM were $37.88 \%, 39.25 \%, 34.22 \%$ and $39.60 \%$, respectively. The highest levels of PUFA were obtained from both LCM ( $42 \%)$ and CCM $(-40 \%)$ in winter. On the other hand, PUFA levels of LCM of male blue crab were $42.64 \%, 41.85 \%$, $41.76 \%$ and $44.01 \%$ while its levels in CCM were $41.13 \%, 40.10 \%, 37.06 \%$ and $40.14 \%$ in spring, summer, autumn and winter, respectively. LCM in winter and CCM in spring gave the highest PUFA contents in male blue crabs. In swimming crab ( $P$. segnis), PUFA levels of LCM of females were found to be $44.97 \%$ in spring, $40.96 \%$ in summer, $42.82 \%$ in autumn, and $46.69 \%$ in winter. PUFA levels in CCM of females were $42.46 \%$ in spring, $39.77 \%$, in summer, $39.48 \%$ in autumn and $44.34 \%$ in winter. PUFA levels of LCM of males were found to be $41.96 \%$ in spring, $44.57 \%$ in summer, $44.35 \%$ in autumn, and $48.40 \%$ in winter whereas its levels in CCM were $43.89 \%, 44.27 \%, 40.56 \%$ and $45.10 \%$, respectively.

The dominant PUFA were linoleic acid (C18:2 n-6), arachidonic acid (C20:4 n-6), cis5,8,11,14, 17-eicosapentaenoic acid (EPA, C20:5 n-3) and cis-4,7,10,13,16,19docosahexaenoic acid (DHA, C22:6 n-3). Significant differences were found $(\mathrm{P}<0.05)$ in the level of EPA and DHA for species, sex and also muscle types.

The highest EPA level of LCM of females' blue crab (C. sapidus) was obtained in autumn (19.19\%), followed by in winter $(18.50 \%)$ whereas CCM gave the highest content of EPA in summer $(17.83 \%)$. EPA levels of LCM of male blue crab were $17.91 \%, 16.32 \%$, $19.75 \%$ and $19.25 \%$ while its levels in CCM were $16.95 \%, 15.92 \%, 16.75 \%$ and $17.56 \%$ in spring, summer, autumn and winter, respectively. Similar to females' blue crab, LCM of male crabs gave the highest EPA content $(19.75 \%)$ in autumn. However, the highest EPA content was obtained from CCM of male blue crab in winter $(17.56 \%)$. The highest EPA level of LCM of females swimming crab (P. segnis) was $20.81 \%$ in spring, followed by $19.60 \%$ in winter while its level of CCM of females' swimming crab was the highest in spring $(18.60 \%)$ and in winter (18.02\%). In male swimming crabs, EPA contents of LCM were $17.92 \%$ in spring, $17.53 \%$ in summer, $18.68 \%$ in autumn and $19.94 \%$ in winter while EPA levels of CCM were $18.67 \%, 17.45 \%, 14.95 \%$ and $18.28 \%$, respectively.

Significant differences $(\mathrm{P}<0.05)$ in DHA contents were observed in terms of sex, seasons and muscle types (Table 5). DHA levels of LCM of female blue crab (C. sapidus) were found to be $12.02 \%$ in spring, $13.07 \%$ in summer, $10.64 \%$ in autumn, and $9.83 \%$ in winter whereas its levels in CCM were $10.34 \%, 11.55 \%, 8.70 \%$ and $8.60 \%$, respectively. The highest levels of DHA were obtained from LCM (13.07\%) and CCM (11.55\%) in summer. On the other hand, DHA levels of LCM of male blue crab were $14.13 \%, 15.40 \%, 11.72 \%$ and $13.02 \%$ while its levels in CCM were $12.22 \%, 12.81 \%, 9.02 \%$ and $9.35 \%$ in spring, summer, 
autumn and winter, respectively. LCM and CCM in summer gave the highest DHA contents in male blue crabs. As for swimming crab (P. segnis), DHA levels of LCM of females were found to be $14.07 \%$ in spring, $13.20 \%$ in summer, $12.90 \%$ in autumn, and $13.88 \%$ in winter whereas DHA levels in CCM of females were $12.42 \%, 12.44 \%, 11.91 \%$ and $12.06 \%$, respectively. DHA levels of LCM of males were found to be $14.14 \%$ in spring, $16.81 \%$ in summer, $13.73 \%$ in autumn, and $15.33 \%$ in winter whereas its levels in CCM were $13.28 \%$, $15.48 \%, 13.14 \%$ and $13.50 \%$, respectively. The highest DHA level in both LCM and CCM was obtained in summer.

\section{Discussion}

The mean carapace width $(\mathrm{CW})$ was $112.0-175.0 \mathrm{~mm}$ for swimming crabs in the present study. In a study by Razek (1988) in the coast of Egypt, males and females of swimming crabs (P. pelagicus) with the CW over $90-100 \mathrm{~mm}$ were accepted as adults. In a similar study carried out by Devi (1985) in Kakinada region of India, males and females of swimming crabs (P. pelagicus) with the CW over $95 \mathrm{~mm}$ were regarded as adults. Thus, males and females of swimming crab (Portunus segnis) in this study were considered as adults (Table 1). In a study carried out by Fisher and Wolff (2006) in Nicoya Gulf in Costa Rica, males and females of blue crabs (Callinectes arcuatus) with the carapace width over $95 \mathrm{~mm}$ were accepted as adults. Thus, according to the results of this study, males and females of blue crabs used in this study were adults (Table 1).

Both crab species were observed to have high protein content in spring and low protein content in autumn. This could have been due to the carapace change of Portunidae crabs in autumn. Gökoğlu \& Yerlikaya (2003) reported protein levels of $14.71 \%, 21.54 \%$ for $C$. sapidus and $P$. pelagicus, respectively. However, Kuley et al. (2008) found higher protein levels in both males and females (27-32\%) regardless of muscle type. In addition, male blue crab meat had higher protein and fat content, and lower moisture and ash content, than those of female crabs. In our previous study (Ayas \& Ozogul, 2011a,b), protein levels of adult female swimming crab (Portunus segnis) were higher than those of males $(\mathrm{p}<0.05)$.

The low lipid content of crabs (Table 2) is a feature of decapods, reported as $<2 \%$ in several studies including Gökoğlu \& Yerlikaya (2003), Kuley et al. (2008) and Ayas \& Ozogul (2011 a,b). The levels of lipid content of both crab species were found to be similar and higher lipid contents in spring and winter, lower lipid contents in summer and autumn for both sexes and muscle types, especially in claw crab meat (CCM) (Table 2). Gates \& Parker (1992) also reported significantly higher fat content in leg meat than claw meat $(0.12 \mathrm{~g} / 100 \mathrm{~g})$ of blue crab. This agrees with our observations in the current study and our previous study (Ayas \& Ozogul, 2011 a,b) and also the results of Kuley et al. (2008). There are factors affecting lipid content of seafood such as environment and season, gender and sexual changes in connection with spawning, period of carapace change (Bell et al., 1985; Bandarra, 1997; Tzikas et al., 2007; Ayas \& Ozogul, 2011 a,b).

The lowest ash content was observed $(\mathrm{P}<0.05)$ in autumn in both crab species. There were also differences $(\mathrm{P}<0.05)$ in the level of ash in both LCM and CCM for both species. Similar results were obtained for claw and body meats of $C$. sapidus by Kuley et al. (2008) and Ayas \& Ozogul (2011 a,b). Since carapace change takes place during August - November in these species, this plays an important role in changing the level of ash content. Ash contents of $C$. sapidus and P. pelagicus were found to be in the range of 1.39-1.89\% and 2.24$2.52 \%$, respectively (Gökoğlu \&Yerlikaya, 2003).

Ayas \& Ozogul (2011 a,b) reported that water levels of males were found to be higher than those of females $(\mathrm{P}<0.05)$. Similar results were found in this study. As for muscle types, 
the moisture content of LCM was found to be higher than those of CCM for both crab species. The highest moisture content was found $(\mathrm{P}<0.05)$ in autumn for both species.

The results of fatty acid compositions indicated that LCM and CCM of swimming crabs and blue crabs were very rich in $n-3$ fatty acids, especially EPA and DHA as reported in previous studies (Ayas \& Ozogul, 2011a,b; Kuley et al., 2008). Kuley et al. (2008) also found that PUFA were the predominant fatty acids found in LCM and CLM of blue crab (Callinectes sapidus). Zlatanos \& Laskaridis (2007) reported that the comparison of the seasonal fat variation with the seasonal fatty acid variation showed a negative correlation between the fat content and the n- 3 fatty acid content for sardine and anchovy, which means that the percentages of $\mathrm{n}-3$ fatty acids were low during the months of high fat content. On the contrary, in this study, the percentages of $n-3$ (EPA and DHA) fatty acids were observed to be higher during seasons of high fat content and also the opposite relation was found for SFA which decreased during season of high fat content, indicating different biological functions for the various fatty acids in the seafood (Zlatanos \& Laskaridis, 2007). It was well documented that the fatty acid composition of fish tissue can be affected by diet, size, age, reproductive cycle, salinity, temperature, season and geographical location (Luzia et al., 2003; Shirai et al., 2002; Styrishave \& Andersen, 2000).

In conclusion, the amount of longer-chain n-3 PUFAs differs among species and can be influenced by a number of factors. Despite the fact that both crabs' species contain small amounts of fat, these organisms are good source of n-3 PUFA content (especially EPA and DHA) for all seasons regardless of sex and muscle types. In addition, these crab species are generally observed to be an excellent protein sources in all seasons $(>20 \%)$ except autumn $(<20 \%)$. Therefore, it would be recommended as a part of diet and also information on the nutrient composition would allow processors to use in the processing, utilization, and marketing of these crab species. 
Table3. Saturated fatty acids (SFA) of the big sea crabs (\%).

\begin{tabular}{|c|c|c|c|c|c|c|c|c|c|c|c|c|}
\hline Season & Species & Sex & $\mathrm{N}$ & $\begin{array}{l}\mathrm{C} 14: 0 \\
\mathrm{X} \pm \mathrm{S}_{\mathrm{X}}\end{array}$ & $\begin{array}{l}\text { C15:0 } \\
X \pm S_{x}\end{array}$ & $\begin{array}{l}\text { C16:0 } \\
X \pm S_{x}\end{array}$ & $\begin{array}{l}\mathrm{C} 17: 0 \\
\mathrm{X} \pm \mathrm{S}_{\mathrm{x}}\end{array}$ & $\begin{array}{l}\mathrm{C} 18: 0 \\
\mathrm{X} \pm \mathrm{S}_{\mathrm{X}}\end{array}$ & $\begin{array}{l}\mathrm{C} 20: 0 \\
\mathrm{X} \pm \mathrm{S}_{\mathrm{X}}\end{array}$ & $\begin{array}{l}\mathrm{C} 22: 0 \\
\mathrm{X} \pm \mathrm{S}_{\mathrm{X}}\end{array}$ & $\Sigma \mathrm{SFA}$ & Muscle \\
\hline & & q & 30 & $0.63 \pm 0.06^{\mathrm{e}}$ & $0.52 \pm 0.01^{\mathrm{cd}}$ & $12.65 \pm 0.14^{d}$ & $1.20 \pm 0.07^{\mathrm{ab}}$ & $8.94 \pm 0.22^{d}$ & $1.11 \pm 0.11^{\mathrm{k}}$ & $0.19 \pm 0.06^{f}$ & 25.24 & LCM \\
\hline Spring & C. sapidus & & 30 & $0.76 \pm 0.07^{f}$ & $0.56 \pm 0.00^{d}$ & $12.71 \pm 0.37^{d}$ & $1.10 \pm 0.07^{a}$ & $7.61 \pm 0.61^{c}$ & $0.73 \pm 0.06^{\mathrm{f}}$ & $0.19 \pm 0.00^{f}$ & 23.65 & CCM \\
\hline \multirow[t]{6}{*}{ (April) } & & $\hat{\sigma}$ & 30 & $0.60 \pm 0.04^{\mathrm{e}}$ & $0.41 \pm 0.01^{b}$ & $12.16 \pm 0.43^{c}$ & $1.30 \pm 0.09^{b}$ & $8.96 \pm 0.56^{d}$ & $1.11 \pm 0.05^{\mathrm{k}}$ & $0.20 \pm 0.03 f$ & 24.74 & LCM \\
\hline & & & 30 & $0.55 \pm 0.05^{d}$ & $0.48 \pm 0.02^{c}$ & $11.57 \pm 0.63^{b c}$ & $1.11 \pm 0.06^{\mathrm{a}}$ & $8.34 \pm 0.39^{\mathrm{cd}}$ & $0.80 \pm 0.17^{\mathrm{f}}$ & $0.16 \pm 0.05^{f}$ & 23.00 & CCM \\
\hline & & q & 30 & $0.73 \pm 0.01^{\mathrm{f}}$ & $0.57 \pm 0.02^{\mathrm{d}}$ & $11.33 \pm 0.07^{\mathrm{b}}$ & $1.21 \pm 0.06^{\mathrm{ab}}$ & $9.33 \pm 0.07^{\mathrm{de}}$ & $0.58 \pm 0.02^{\mathrm{de}}$ & $0.13 \pm 0.01^{\mathrm{ef}}$ & 23.88 & LCM \\
\hline & P. segnis & & 30 & $0.80 \pm 0.01^{\mathrm{fg}}$ & $0.59 \pm 0.02^{\mathrm{de}}$ & $11.31 \pm 0.04^{\mathrm{b}}$ & $1.22 \pm 0.04^{\mathrm{ab}}$ & $8.93 \pm 0.07^{\mathrm{d}}$ & $0.66 \pm 0.04^{\mathrm{ef}}$ & $0.13 \pm 0.01^{\mathrm{ef}}$ & 23.63 & CCM \\
\hline & & $\hat{0}$ & 30 & $1.15 \pm 0.05^{\mathrm{h}}$ & $0.56 \pm 0.02^{\mathrm{d}}$ & $12.76 \pm 0.04^{\mathrm{d}}$ & $1.25 \pm 0.05^{\mathrm{ab}}$ & $10.28 \pm 0.07^{\mathrm{g}}$ & $1.04 \pm 0.03^{\mathrm{h}}$ & $0.44 \pm 0.01^{\mathrm{g}}$ & 27.48 & LCM \\
\hline & & $q$ & 30 & $0.47 \pm 0.02^{\text {cd }}$ & $0.52 \pm 0.03^{c d}$ & $15.36 \pm 0.15^{\mathrm{g}}$ & $1.25 \pm 0.05^{\mathrm{a}}$ & $9.88 \pm 0.10^{f}$ & $0.73 \pm 0.05^{\mathrm{f}}$ & $0.04 \pm 0.01^{\text {ab }}$ & 28.25 & LCM \\
\hline \multirow{7}{*}{$\begin{array}{l}\text { Summer } \\
\text { (July) }\end{array}$} & C. sapidus & & 30 & $0.51 \pm 0.03^{\mathrm{d}}$ & $\mathbf{0 . 5 7} \pm \mathbf{0 . 0 3 ^ { d }}$ & $15.12 \pm 0.12^{\mathrm{g}}$ & $1.30 \pm 0.04^{b}$ & $8.89 \pm 0.06^{d}$ & $0.60 \pm 0.02^{\mathrm{e}}$ & $0.03 \pm 0.01^{\mathrm{a}}$ & 27.02 & CCM \\
\hline & & $\hat{\sigma}$ & 30 & $0.66 \pm 0.03^{\mathrm{e}}$ & $0.46 \pm 0.02^{c}$ & $13.02 \pm 0.15^{\text {de }}$ & $1.74 \pm 0.03^{\mathrm{f}}$ & $11.93 \pm 0.15^{\mathrm{m}}$ & $0.78 \pm 0.03^{\mathrm{f}}$ & $0.04 \pm 0.00^{a}$ & 28.63 & LCM \\
\hline & & & 30 & $0.38 \pm 0.02^{b}$ & $0.51 \pm 0.03^{c}$ & $13.45 \pm 0.10^{\mathrm{e}}$ & $1.77 \pm 0.05^{\mathrm{f}}$ & $10.68 \pm 0.11^{h}$ & $0.60 \pm 0.05^{\mathrm{e}}$ & ND & 27.38 & CCM \\
\hline & P. segnis & q & 30 & $0.42 \pm 0.01^{\mathrm{c}}$ & $0.54 \pm 0.01^{\mathrm{cd}}$ & $12.74 \pm 0.13^{\mathrm{d}}$ & $1.40 \pm 0.02^{\mathrm{c}}$ & $11.81 \pm 0.11^{\mathrm{m}}$ & $0.55 \pm 0.01^{\mathrm{d}}$ & $0.05 \pm 0.00^{\mathrm{b}}$ & 27.51 & LCM \\
\hline & & & 30 & $0.76 \pm 0.02^{\mathrm{f}}$ & $0.58 \pm 0.03^{\mathrm{d}}$ & $12.44 \pm 0.10^{\mathrm{cd}}$ & $1.33 \pm 0.01^{\mathrm{b}}$ & $10.86 \pm 0.07^{\mathrm{kl}}$ & $0.63 \pm 0.01^{\mathrm{e}}$ & $0.08 \pm 0.00^{c}$ & 26.68 & CCM \\
\hline & & 0 & 30 & $0.27 \pm 0.00^{\mathrm{a}}$ & $0.58 \pm 0.03^{\mathrm{d}}$ & $11.01 \pm 0.06^{\mathrm{a}}$ & $1.88 \pm 0.03^{\mathrm{fg}}$ & $13.32 \pm 0.11^{\mathrm{n}}$ & $0.61 \pm 0.01^{\mathrm{e}}$ & $0.05 \pm 0.01^{\mathrm{b}}$ & 27.72 & LCM \\
\hline & & & 30 & $0.42 \pm 0.02^{\mathrm{c}}$ & $0.76 \pm 0.03^{\mathrm{f}}$ & $11.32 \pm 0.07^{\mathrm{b}}$ & $1.66 \pm 0.01^{\mathrm{ef}}$ & $9.97 \pm 0.13^{\mathrm{fg}}$ & $0.46 \pm 0.01^{\mathrm{b}}$ & ND & 24.59 & CCM \\
\hline \multirow{7}{*}{$\begin{array}{l}\text { Autumn } \\
\text { (October) }\end{array}$} & & q & 30 & $0.59 \pm 0.02^{\mathrm{e}}$ & $0.45 \pm 0.01^{c}$ & $13.57 \pm 0.12^{\text {ef }}$ & $1.31 \pm 0.05^{b}$ & $10.49 \pm 0.17^{\mathrm{h}}$ & $0.83 \pm 0.04^{f}$ & $0.17 \pm 0.02^{f}$ & 27.41 & LCM \\
\hline & & $\hat{0}$ & 30 & $\mathbf{0 . 3 7} \pm 0.04^{b}$ & $\mathbf{0 . 3 4} \pm 0.00^{\mathrm{a}}$ & $12.11 \pm 0.16^{\mathrm{c}}$ & $1.97 \pm 0.04^{\mathrm{g}}$ & $10.48 \pm 0.27^{h}$ & $0.69 \pm 0.02^{f}$ & $0.09 \pm 0.00^{d}$ & 26.04 & LCM \\
\hline & & & 30 & $0.36 \pm 0.01^{b}$ & $0.45 \pm 0.01^{c}$ & $12.95 \pm 0.01^{d}$ & $2.04 \pm 0.01^{g}$ & $9.37 \pm 0.03^{\mathrm{e}}$ & $0.64 \pm 0.01^{\text {ef }}$ & $0.04 \pm 0.00^{a}$ & 25.85 & CCM \\
\hline & P. segnis & q & 30 & $0.52 \pm 0.03^{\mathrm{d}}$ & $0.51 \pm 0.04^{\mathrm{c}}$ & $12.38 \pm 0.29^{\mathrm{cd}}$ & $1.53 \pm 0.02^{\mathrm{d}}$ & $11.23 \pm 0.12^{1}$ & $0.61 \pm 0.01^{\mathrm{e}}$ & $0.10 \pm 0.01^{\mathrm{e}}$ & 26.89 & LCM \\
\hline & & & 30 & $0.86 \pm 0.07^{\mathrm{g}}$ & $0.56 \pm 0.03^{\mathrm{d}}$ & $12.89 \pm 0.20^{\mathrm{d}}$ & $1.48 \pm 0.03^{\mathrm{c}}$ & $10.61 \pm 0.34^{\mathrm{h}}$ & $0.62 \pm 0.02^{\mathrm{e}}$ & $0.09 \pm 0.01^{\mathrm{de}}$ & 27.11 & CCM \\
\hline & & $\widehat{0}$ & 30 & $0.44 \pm 0.03^{\mathrm{c}}$ & $0.54 \pm 0.03^{\mathrm{cd}}$ & $11.91 \pm 0.06^{\mathrm{c}}$ & $1.62 \pm 0.05^{\mathrm{e}}$ & $10.74 \pm 0.24^{\mathrm{hk}}$ & $0.54 \pm 0.04^{\mathrm{d}}$ & $0.08 \pm 0.00^{\mathrm{ab}}$ & 25.88 & LCM \\
\hline & & & 30 & $0.74 \pm 0.04^{\mathrm{f}}$ & $0.66 \pm 0.00^{\mathrm{e}}$ & $13.75 \pm 0.09^{\mathrm{f}}$ & $1.61 \pm 0.02^{\mathrm{e}}$ & $9.78 \pm 0.18^{\mathrm{f}}$ & $0.49 \pm 0.00^{\mathrm{c}}$ & $0.07 \pm 0.01^{\mathrm{bc}}$ & 27.10 & CCM \\
\hline \multirow{8}{*}{$\begin{array}{l}\text { Winter } \\
\text { (December) }\end{array}$} & & q & 30 & $0.51 \pm 0.06^{\mathrm{d}}$ & $0.80 \pm 0.08^{f}$ & $10.61 \pm 0.21^{\mathrm{a}}$ & $1.46 \pm 0.09^{c}$ & $7.15 \pm 0.13^{b}$ & $0.94 \pm 0.09^{g}$ & $0.17 \pm 0.02^{f}$ & 21.63 & LCM \\
\hline & C. sapidus & & 30 & $0.85 \pm 0.11^{g}$ & $0.89 \pm 0.10^{f}$ & $11.93 \pm 0.07^{c}$ & $1.42 \pm 0.10^{c}$ & $6.12 \pm 0.42^{\mathrm{a}}$ & $0.77 \pm 0.10^{\mathrm{f}}$ & $0.11 \pm 0.01^{\mathrm{e}}$ & 22.09 & CCM \\
\hline & & $\widehat{\sigma}$ & 30 & $0.52 \pm 0.03^{\mathrm{d}}$ & $0.52 \pm 0.02^{\mathrm{cd}}$ & $12.34 \pm 0.35^{\mathrm{cd}}$ & $1.74 \pm 0.05^{\mathrm{f}}$ & $8.90 \pm 0.10^{\mathrm{d}}$ & $0.70 \pm 0.06^{\mathrm{f}}$ & $0.09 \pm 0.00^{d}$ & 24.82 & $\mathrm{LCM}$ \\
\hline & & & 30 & $0.66 \pm 0.06^{\mathrm{e}}$ & $0.85 \pm 0.05^{f}$ & $12.66 \pm 0.15^{c}$ & $1.64 \pm 0.08^{\mathrm{e}}$ & $7.02 \pm 0.02^{b}$ & $0.78 \pm 0.02^{\mathrm{f}}$ & $0.04 \pm 0.00^{\mathrm{a}}$ & 23.64 & ССМ \\
\hline & P. segnis & q & 30 & $0.55 \pm 0.07^{\mathrm{d}}$ & $0.62 \pm 0.01^{\mathrm{e}}$ & $11.84 \pm 0.18^{c}$ & $1.69 \pm 0.06^{\mathrm{ef}}$ & $9.75 \pm 0.24^{\mathrm{f}}$ & $0.63 \pm 0.02^{\mathrm{e}}$ & $0.10 \pm 0.00^{\mathrm{e}}$ & 25.18 & LCM \\
\hline & & & 30 & $0.68 \pm 0.03^{\mathrm{ef}}$ & $0.63 \pm 0.04^{\mathrm{e}}$ & $11.35 \pm 0.28^{\mathrm{b}}$ & $1.49 \pm 0.08^{\mathrm{d}}$ & $8.61 \pm 0.35^{\mathrm{cd}}$ & $0.54 \pm 0.02^{\mathrm{d}}$ & $0.08 \pm 0.00^{\mathrm{c}}$ & 23.37 & CCM \\
\hline & & 0 & 30 & $0.51 \pm 0.04^{\mathrm{d}}$ & $0.49 \pm 0.02^{c}$ & $10.88 \pm 0.27^{\mathrm{a}}$ & $1.66 \pm 0.08^{\mathrm{ef}}$ & $10.74 \pm 0.29^{\mathrm{hk}}$ & $0.44 \pm 0.02^{b}$ & $0.08 \pm 0.00^{c}$ & 24.79 & LCM \\
\hline & & & 30 & $0.66 \pm 0.05^{\mathrm{e}}$ & $0.57 \pm 0.02^{\mathrm{d}}$ & $11.53 \pm 0.32^{\mathrm{bc}}$ & $1.53 \pm 0.01^{\mathrm{d}}$ & $9.19 \pm 0.17^{\mathrm{d}}$ & $0.35 \pm 0.02^{\mathrm{a}}$ & $0.06 \pm 0.00^{\mathrm{b}}$ & 23.90 & CCM \\
\hline
\end{tabular}

Value in same column with different letters are significantly different $(\mathrm{P}<0.05) . \quad \overline{\mathrm{X}} \pm \mathrm{S}_{\mathrm{x}}:$ Standard deviation 
Table 4. Monounsaturated fatty acids (MUFA) of the big sea crabs (\%).

\begin{tabular}{|c|c|c|c|c|c|c|c|c|c|c|c|c|}
\hline Season & Species & Sex & $\mathrm{N}$ & $\begin{array}{l}\mathrm{C} 14: 1 \\
\bar{X} \pm S_{\mathrm{x}}\end{array}$ & $\begin{array}{l}\mathrm{C} 15: 1 \\
\bar{X} \pm S_{\mathrm{x}}\end{array}$ & $\begin{array}{l}\mathrm{C} 16: 1 \\
\bar{X} \pm S_{\mathrm{x}}\end{array}$ & $\begin{array}{l}\mathrm{C} 17: 1 \\
\bar{X} \pm S_{\mathrm{x}}\end{array}$ & $\begin{array}{l}\mathrm{C} 18: 1 n 9 \\
\overline{\mathrm{X}}_{ \pm \mathrm{S}_{\mathrm{x}}}\end{array}$ & $\begin{array}{l}\mathrm{C} 18: 1 n 7 \\
\overline{\mathrm{X}} \pm \mathrm{S}_{\mathrm{x}}\end{array}$ & $\begin{array}{l}\mathrm{C} 20: 1 \\
\bar{X} \pm S_{x}\end{array}$ & $\Sigma$ MUFA & Muscle \\
\hline \multirow{8}{*}{$\begin{array}{l}\text { Spring } \\
\text { (April) }\end{array}$} & \multirow{2}{*}{ C. sapidus } & $q$ & 30 & $0.04 \pm 0.011^{c}$ & $0.12 \pm 0.00^{c}$ & $7.10 \pm 0.10^{k}$ & $0.98 \pm 0.03^{b}$ & $13.79 \pm 0.14^{d}$ & $3.81 \pm 0.01^{\circ}$ & $\begin{array}{l}0.40 \pm 0.02 \\
\text { gh }\end{array}$ & 26.24 & LCM \\
\hline & & & 30 & $0.03 \pm 0.01^{b c}$ & $0.12 \pm 0.00^{c}$ & $7.88 \pm 0.11^{\mathrm{m}}$ & $1.17 \pm 0.03^{d}$ & $15.20 \pm 0.09^{f}$ & $3.34 \pm 0.05^{1}$ & $\begin{array}{l}0.31 \pm 0.02 \\
\mathrm{~g}\end{array}$ & 28.04 & CCM \\
\hline & \multirow{6}{*}{ P. segnis } & $\widehat{0}$ & 30 & $0.03 \pm 0.00^{b}$ & $0.10 \pm 0.01^{b}$ & $4.48 \pm 0.14^{\mathrm{c}}$ & $0.89 \pm 0.02^{\mathrm{ab}}$ & $12.96 \pm 0.25^{b c}$ & $4.32 \pm 0.08^{p}$ & $\begin{array}{l}0.43 \pm 0.05 \\
h\end{array}$ & 23.22 & LCM \\
\hline & & & 30 & $0.03 \pm 0.00^{b}$ & $0.11 \pm 0.01^{c}$ & $5.54 \pm 0.10^{c}$ & $1.21 \pm 0.05^{\mathrm{d}}$ & $14.90 \pm 0.49^{e}$ & $3.68 \pm 0.03^{n}$ & $\underset{\text { gh }}{0.39 \pm 0.06}$ & 25.86 & $\mathbf{C C M}$ \\
\hline & & q & 30 & $0.04 \pm 0.01^{\mathrm{c}}$ & $0.15 \pm 0.00^{\mathrm{e}}$ & $6.47 \pm 0.10^{\mathrm{g}}$ & $0.91 \pm 0.04^{b}$ & $12.58 \pm 0.12^{\mathrm{b}}$ & $3.04 \pm 0.02^{\mathrm{c}}$ & $0.14 \pm 0.01^{\mathrm{c}}$ & 23.32 & LCM \\
\hline & & & 30 & $0.04 \pm 0.00^{\mathrm{c}}$ & $0.16 \pm 0.01^{\mathrm{f}}$ & $6.89 \pm 0.01^{\mathrm{h}}$ & $1.04 \pm 0.02^{\mathrm{c}}$ & $15.56 \pm 0.05^{\mathrm{g}}$ & $2.81 \pm 0.01^{\mathrm{h}}$ & $\begin{array}{l}0.16 \pm 0.01 \\
\mathrm{~d}\end{array}$ & 26.67 & CCM \\
\hline & & $\widehat{\delta}$ & 30 & $0.05 \pm 0.01^{\mathrm{c}}$ & $0.14 \pm 0.00^{\mathrm{c}}$ & $4.92 \pm 0.10^{\mathrm{e}}$ & $0.81 \pm 0.03^{\mathrm{a}}$ & $15.12 \pm 0.11^{\mathrm{f}}$ & $3.03 \pm 0.06^{\mathrm{h}}$ & $\begin{array}{l}0.17 \pm 0.01 \\
\mathrm{~d}\end{array}$ & 24.23 & LCM \\
\hline & & & 30 & $0.04 \pm 0.01^{\mathrm{c}}$ & $0.15 \pm 0.01^{\mathrm{e}}$ & $5.63 \pm 0.03^{\mathrm{f}}$ & $1.08 \pm 0.04^{\mathrm{cd}}$ & $15.03 \pm 0.02^{\mathrm{f}}$ & $2.70 \pm 0.01^{\mathrm{g}}$ & $\begin{array}{l}0.17 \pm 0.01 \\
\text { d }\end{array}$ & 24.80 & CCM \\
\hline \multirow{8}{*}{$\begin{array}{l}\text { Summer } \\
\text { (July) }\end{array}$} & \multirow{3}{*}{ C. sapidus } & q & 30 & $0.04 \pm 0.01^{c}$ & $0.11 \pm 0.01^{c}$ & $7.59 \pm 0.10^{1}$ & $0.92 \pm 0.05^{b}$ & $13.28 \pm 0.20^{c}$ & $3.10 \pm 0.00^{k}$ & $\begin{array}{l}\mathbf{0 . 3 5} \pm 0.05 \\
\mathrm{~g}\end{array}$ & 25.39 & LCM \\
\hline & & & 30 & $0.05 \pm 0.01^{\mathrm{c}}$ & $0.11 \pm 0.01^{c}$ & $8.36 \pm 0.10^{n}$ & $1.26 \pm 0.03^{d}$ & $13.94 \pm 0.14^{d}$ & $3.29 \pm 0.01^{1}$ & $\begin{array}{l}\mathbf{0 . 3 3} \pm \mathbf{0 . 0 3} \\
\mathrm{g}\end{array}$ & 27.33 & CCM \\
\hline & & $\hat{0}$ & 30 & $0.03 \pm 0.00^{b}$ & $0.09 \pm 0.01^{b}$ & $4.16 \pm 0.11^{b c}$ & $1.15 \pm 0.05^{d}$ & $13.34 \pm 0.20^{b}$ & $3.37 \pm 0.03^{1}$ & $\begin{array}{l}\mathbf{0 . 5 0} \pm 0.03 \\
h\end{array}$ & 22.64 & LCM \\
\hline & \multirow{5}{*}{ P. segnis } & & 30 & ND & $0.10 \pm 0.01^{b}$ & $4.53 \pm 0.07^{\mathrm{c}}$ & $1.49 \pm 0.02^{\mathrm{d}}$ & $16.02 \pm 0.20^{k}$ & $3.35 \pm 0.01^{1}$ & $0.26 \pm 0.00^{f}$ & 25.75 & $\mathbf{C C M}$ \\
\hline & & q & 30 & ND & $0.13 \pm 0.00^{\mathrm{d}}$ & $7.28 \pm 0.12^{\mathrm{k}}$ & $0.97 \pm 0.03^{c}$ & $13.70 \pm 0.10^{\mathrm{d}}$ & $2.66 \pm 0.03^{\mathrm{g}}$ & $\begin{array}{l}0.12 \pm 0.00 \\
\text { b }\end{array}$ & 24.86 & LCM \\
\hline & & & 30 & $0.03 \pm 0.00^{\mathrm{b}}$ & $0.14 \pm 0.01^{\mathrm{c}}$ & $7.72 \pm 0.04^{\mathrm{f}}$ & $0.99 \pm 0.01^{\mathrm{c}}$ & $14.58 \pm 0.11^{\mathrm{e}}$ & $2.67 \pm 0.01^{\mathrm{g}}$ & $\underset{d}{0.15 \pm 0.01^{c}}$ & 26.28 & $\mathbf{C C M}$ \\
\hline & & $\hat{0}$ & 30 & ND & $0.16 \pm 0.00^{\mathrm{f}}$ & $3.43 \pm 0.03^{\mathrm{a}}$ & $0.93 \pm 0.05^{\mathrm{b}}$ & $12.47 \pm 0.10^{\mathrm{b}}$ & $2.39 \pm 0.01^{\mathrm{f}}$ & $\begin{array}{l}0.16 \pm 0.02 \\
\text { d }\end{array}$ & 19.54 & LCM \\
\hline & & & 30 & ND & $0.21 \pm 0.01^{\mathrm{g}}$ & $4.70 \pm 0.03^{\mathrm{d}}$ & $1.27 \pm 0.02^{\mathrm{d}}$ & $15.04 \pm 0.05^{\mathrm{f}}$ & $1.62 \pm 0.02^{\mathrm{b}}$ & $\begin{array}{l}0.10 \pm 0.00 \\
\mathrm{~b}\end{array}$ & 22.94 & CCM \\
\hline \multirow{2}{*}{$\begin{array}{l}\text { Autumn } \\
\text { (October) }\end{array}$} & \multirow[t]{2}{*}{ C. sapidus } & q & 30 & $0.03 \pm 0.00^{b}$ & $0.09 \pm 0.00^{b}$ & $7.77 \pm 0.50^{\mathrm{m}}$ & $1.08 \pm 0.04^{\text {cd }}$ & $15.69 \pm 0.01^{\mathrm{g}}$ & $2.29 \pm 0.02^{\mathrm{e}}$ & $\begin{array}{l}0.54 \pm 0.01 \\
k\end{array}$ & 27.48 & LCM \\
\hline & & & 30 & $0.04 \pm 0.00^{c}$ & $\mathrm{e}^{0.13 \pm 0.01^{\mathrm{d}}}$ & $9.10 \pm 0.12^{\circ}$ & $1.39 \pm 0.01^{\mathrm{e}}$ & $17.95 \pm 0.01^{1}$ & $1.93 \pm 0.01^{\mathrm{c}}$ & $\begin{array}{l}0.54 \pm 0.12 \\
k\end{array}$ & 31.08 & CCM \\
\hline
\end{tabular}




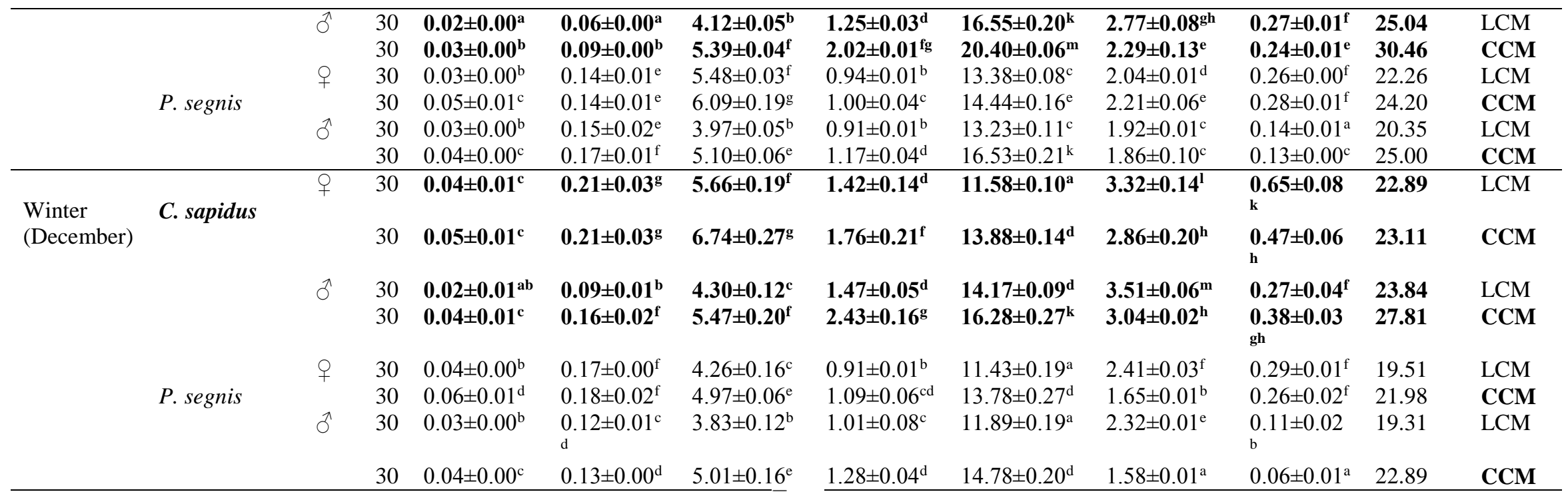

Value in same column with different letters are significantly different $(\mathrm{P}<0.05) . \quad \overline{\mathrm{X}} \pm \mathrm{S}_{\mathrm{x}}:$ Standard deviation

Table 5. Polyunsaturated fatty acids (PUFA) of the big sea crabs (\%).

\begin{tabular}{|c|c|c|c|c|c|c|c|c|c|c|c|c|}
\hline Season & Species & Sex & $\mathrm{N}$ & $\begin{array}{l}\mathrm{C} 18: 2 n 6 \\
\mathrm{X} \pm \mathrm{S}_{\mathrm{X}}\end{array}$ & $\begin{array}{l}\mathrm{C} 18: 3 n 6 \\
\mathrm{X} \pm \mathrm{S}_{\mathrm{X}}\end{array}$ & $\begin{array}{l}\mathrm{C} 18: 3 n 3 \\
\mathrm{X} \pm \mathrm{S}_{\mathrm{X}}\end{array}$ & $\begin{array}{l}\mathrm{C} 20: 4 n 6 \\
\mathrm{X} \pm \mathrm{S}_{\mathrm{X}}\end{array}$ & $\begin{array}{l}\mathrm{C} 20: 5 n 3 \\
\mathrm{X} \pm \mathrm{S}_{\mathrm{X}}\end{array}$ & $\begin{array}{l}\mathrm{C} 22: 2 \text { cis } \\
\mathrm{X} \pm \mathrm{S}_{\mathrm{X}}\end{array}$ & $\begin{array}{l}\mathrm{C} 22: 6 n 3 \\
\mathrm{X} \pm \mathrm{S}_{\mathrm{x}}\end{array}$ & $\Sigma$ PUFA & Muscle \\
\hline \multirow{8}{*}{$\begin{array}{l}\text { Spring } \\
\text { (April) }\end{array}$} & \multirow{4}{*}{ C. sapidus } & $q$ & 30 & $2.76 \pm 0.46^{\mathrm{cd}}$ & $0.16 \pm 0.02^{a}$ & $0.84 \pm 0.10^{e}$ & $4.93 \pm 0.21^{\mathrm{a}}$ & $17.89 \pm 0.33^{g}$ & $0.35 \pm 0.01^{\text {ef }}$ & $12.02 \pm 0.34^{\mathrm{e}}$ & 38.94 & LCM \\
\hline & & & 30 & $3.08 \pm 0.07^{d}$ & $0.13 \pm 0.03^{b c}$ & $0.84 \pm 0.01^{\mathrm{e}}$ & $6.38 \pm 0.37^{c}$ & $16.79 \pm 0.03^{d}$ & $0.32 \pm 0.02^{\text {def }}$ & $10.34 \pm 0.20^{d}$ & 37.88 & CCM \\
\hline & & o & 30 & $3.34 \pm 0.29^{d}$ & $0.18 \pm 0.01^{\mathrm{cd}}$ & $0.91 \pm 0.04^{\mathrm{ef}}$ & $5.84 \pm 0.18^{b}$ & $17.91 \pm 0.17^{\mathrm{g}}$ & $0.33 \pm 0.02^{\text {def }}$ & $14.13 \pm 0.48^{h}$ & 42.64 & LCM \\
\hline & & & 30 & $3.04 \pm 0.48^{d}$ & $0.19 \pm 0.04^{\mathrm{cd}}$ & $0.74 \pm 0.02^{\text {de }}$ & $7.68 \pm 0.05^{d}$ & $16.95 \pm 0.06^{\mathrm{e}}$ & $0.30 \pm 0.04^{\text {cde }}$ & $12.22 \pm 0.24^{\mathrm{ef}}$ & 41.13 & CCM \\
\hline & \multirow{4}{*}{ P. segnis } & q & 30 & $2.27 \pm 0.05^{\mathrm{b}}$ & $0.30 \pm 0.01^{\mathrm{e}}$ & $0.58 \pm 0.02^{\mathrm{c}}$ & $6.62 \pm 0.04^{\mathrm{c}}$ & $20.81 \pm 0.06^{\mathrm{n}}$ & $0.31 \pm 0.01^{\mathrm{de}}$ & $14.07 \pm 0.07^{\mathrm{h}}$ & 44.97 & LCM \\
\hline & & & 30 & $3.02 \pm 0.04^{\mathrm{d}}$ & $0.24 \pm 0.01^{\mathrm{d}}$ & $0.58 \pm 0.02^{\mathrm{c}}$ & $7.28 \pm 0.04^{\mathrm{d}}$ & $18.60 \pm 0.01^{\mathrm{k}}$ & $0.33 \pm 0.02^{\mathrm{def}}$ & $12.42 \pm 0.08^{\mathrm{fg}}$ & 42.46 & CCM \\
\hline & & $\hat{0}$ & 30 & $2.36 \pm 0.06^{b}$ & $0.26 \pm 0.01^{\mathrm{d}}$ & $0.45 \pm 0.01^{\mathrm{b}}$ & $6.55 \pm 0.05^{\mathrm{c}}$ & $17.92 \pm 0.07^{\mathrm{g}}$ & $0.26 \pm 0.02^{\mathrm{abc}}$ & $14.14 \pm 0.03^{\mathrm{h}}$ & 41.96 & LCM \\
\hline & & & 30 & $2.30 \pm 0.01^{\mathrm{b}}$ & $0.25 \pm 0.01^{\mathrm{d}}$ & $0.47 \pm 0.01^{\mathrm{b}}$ & $8.63 \pm 0.09^{f}$ & $18.67 \pm 0.04^{\mathrm{k}}$ & $0.30 \pm 0.01^{\text {cde }}$ & $13.28 \pm 0.11^{\mathrm{gh}}$ & 43.89 & CCM \\
\hline \multirow{5}{*}{$\begin{array}{l}\text { Summer } \\
\text { (July) }\end{array}$} & \multirow{5}{*}{ C. sapidus } & q & 30 & $2.58 \pm 0.15^{c}$ & $0.14 \pm 0.02^{b c}$ & $0.81 \pm 0.05^{\mathrm{e}}$ & $5.29 \pm 0.10^{\mathrm{a}}$ & $17.48 \pm 0.20^{f}$ & $0.29 \pm 0.02^{\text {cde }}$ & $13.07 \pm 0.20^{\mathrm{g}}$ & 39.95 & LCM \\
\hline & & & 30 & $2.26 \pm 0.02^{b}$ & $0.11 \pm 0.01^{b}$ & $0.74 \pm 0.04^{d e}$ & $6.11 \pm 0.11^{b}$ & $17.83 \pm 0.13^{\mathrm{g}}$ & $0.34 \pm 0.01^{\text {ef }}$ & $11.55 \pm 0.15^{\mathrm{e}}$ & 39.25 & CCM \\
\hline & & $\widehat{0}$ & 30 & $2.77 \pm 0.05^{\mathrm{cd}}$ & $0.12 \pm 0.01^{b}$ & $0.60 \pm 0.02^{c d}$ & $6.07 \pm 0.07^{b}$ & $16.32 \pm 0.10^{c}$ & $0.27 \pm 0.00^{b}$ & $15.40 \pm 0.10^{\mathrm{k}}$ & 41.85 & LCM \\
\hline & & & 30 & $2.75 \pm 0.05^{\mathrm{cd}}$ & $0.11 \pm 0.00^{\mathrm{a}}$ & $0.71 \pm 0.04^{d}$ & $7.29 \pm 0.14^{\mathrm{d}}$ & $15.92 \pm 0.20^{c}$ & $0.28 \pm 0.02^{b c}$ & $12.81 \pm 0.15^{\mathrm{g}}$ & 40.10 & CCM \\
\hline & & 우 & 30 & $2.16 \pm 0.04^{\mathrm{a}}$ & $0.17 \pm 0.01^{\mathrm{c}}$ & $0.40 \pm 0.00^{\mathrm{a}}$ & $6.23 \pm 0.07^{\mathrm{c}}$ & $18.32 \pm 0.13^{\mathrm{h}}$ & $0.27 \pm 0.01^{\mathrm{bc}}$ & $13.20 \pm 0.05^{\mathrm{gh}}$ & 40.96 & LCM \\
\hline
\end{tabular}




\begin{tabular}{|c|c|c|c|c|c|c|c|c|c|c|c|c|}
\hline \multirow[t]{3}{*}{ 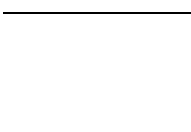 } & \multirow[t]{3}{*}{ P. segnis } & \multirow{3}{*}{$\widehat{\sigma}$} & 30 & $2.14 \pm 0.05^{\mathrm{a}}$ & $0.15 \pm 0.00^{\mathrm{c}}$ & $0.40 \pm 0.01^{\mathrm{a}}$ & $7.48 \pm 0.08^{\mathrm{d}}$ & $16.60 \pm 0.10^{\mathrm{d}}$ & $0.29 \pm 0.00^{\mathrm{c}}$ & $12.44 \pm 0.15^{\mathrm{fg}}$ & 39.77 & CCM \\
\hline & & & 30 & $2.47 \pm 0.07^{b c}$ & $0.16 \pm 0.01^{\mathrm{c}}$ & $0.63 \pm 0.02^{\mathrm{d}}$ & $6.39 \pm 0.04^{c}$ & $17.53 \pm 0.08^{f}$ & $0.32 \pm 0.01^{\mathrm{de}}$ & $16.81 \pm 0.20^{1}$ & 44.57 & LCM \\
\hline & & & 30 & $2.21 \pm 0.02^{\mathrm{ab}}$ & $0.13 \pm 0.01^{\mathrm{b}}$ & $0.59 \pm 0.02^{\mathrm{c}}$ & $7.76 \pm 0.06^{\mathrm{d}}$ & $17.45 \pm 0.10^{\mathrm{f}}$ & $0.37 \pm 0.01^{\mathrm{f}}$ & $15.48 \pm 0.06^{\mathrm{k}}$ & 44.27 & $\mathrm{CCM}$ \\
\hline \multirow{8}{*}{$\begin{array}{l}\text { Autumn } \\
\text { (October) }\end{array}$} & \multirow{3}{*}{ C. sapidus } & \multirow[t]{2}{*}{ q } & 30 & $2.33 \pm 0.09^{b}$ & $0.09 \pm 0.01^{a}$ & $0.94 \pm 0.06^{f}$ & $6.10 \pm 0.19^{b}$ & $19.19 \pm 0.17^{\mathrm{l}}$ & $0.21 \pm 0.01^{a}$ & $10.64 \pm 0.06^{d}$ & 39.77 & LCM \\
\hline & & & 30 & $2.23 \pm 0.03^{b}$ & $0.12 \pm 0.00^{b}$ & $0.95 \pm 0.02^{\mathrm{f}}$ & $6.66 \pm 0.17^{c}$ & $15.05 \pm 0.22^{\mathrm{a}}$ & $0.25 \pm 0.01^{\mathrm{ab}}$ & $8.70 \pm 0.18^{a b}$ & 34.22 & $\mathrm{CCM}$ \\
\hline & & \multirow[t]{2}{*}{$\widehat{0}$} & 30 & $2.87 \pm 0.09^{d}$ & $0.15 \pm 0.01^{c}$ & $0.95 \pm 0.02^{\mathrm{f}}$ & $5.79 \pm 0.19^{b}$ & $19.75 \pm 0.51^{\mathrm{m}}$ & $0.29 \pm 0.01^{\mathrm{cd}}$ & $11.72 \pm 0.40^{\mathrm{e}}$ & 41.76 & LCM \\
\hline & \multirow{5}{*}{ P. segnis } & & 30 & $3.17 \pm 0.03^{d}$ & $0.15 \pm 0.01^{c}$ & $0.86 \pm 0.01^{e}$ & $6.65 \pm 0.01^{c}$ & $16.75 \pm 0.05^{d}$ & $0.26 \pm 0.01^{\mathrm{ab}}$ & $9.02 \pm 0.08^{b}$ & 37.06 & CCM \\
\hline & & \multirow[t]{2}{*}{ q } & 30 & $2.45 \pm 0.03^{b c}$ & $0.13 \pm 0.01^{\mathrm{b}}$ & $0.64 \pm 0.04^{\mathrm{d}}$ & $7.75 \pm 0.24^{\mathrm{d}}$ & $18.44 \pm 0.09^{h}$ & $0.24 \pm 0.02^{\mathrm{a}}$ & $12.90 \pm 0.05^{\mathrm{g}}$ & 42.82 & LCM \\
\hline & & & 30 & $2.00 \pm 0.10^{\mathrm{a}}$ & $0.09 \pm 0.01^{\mathrm{a}}$ & $0.59 \pm 0.04^{\mathrm{c}}$ & $8.84 \pm 0.04^{\mathrm{c}}$ & $15.52 \pm 0.03^{b}$ & $0.26 \pm 0.02^{\mathrm{abc}}$ & $11.91 \pm 0.12^{\mathrm{e}}$ & 39.48 & CCM \\
\hline & & \multirow[t]{2}{*}{$\hat{\sigma}$} & 30 & $2.57 \pm 0.17^{\mathrm{c}}$ & $0.12 \pm 0.01^{\mathrm{b}}$ & $0.58 \pm 0.02^{\mathrm{c}}$ & $8.12 \pm 0.01^{\mathrm{e}}$ & $18.68 \pm 0.02^{\mathrm{k}}$ & $0.29 \pm 0.02^{\mathrm{b}}$ & $13.73 \pm 0.13^{\mathrm{h}}$ & 44.35 & LCM \\
\hline & & & 30 & $2.61 \pm 0.15^{\mathrm{c}}$ & $0.09 \pm 0.00^{\mathrm{a}}$ & $0.60 \pm 0.01^{\mathrm{cd}}$ & $8.64 \pm 0.19^{f}$ & $14.95 \pm 0.08^{\mathrm{a}}$ & $0.29 \pm 0.02^{\text {cde }}$ & $13.14 \pm 0.13^{\mathrm{gh}}$ & 40.56 & $\mathrm{CCM}$ \\
\hline \multirow{8}{*}{$\begin{array}{l}\text { Winter } \\
\text { (December) }\end{array}$} & \multirow{3}{*}{ C. sapidus } & \multirow[t]{2}{*}{ q } & 30 & $2.42 \pm 0.04^{b c}$ & $0.09 \pm 0.01^{a}$ & $0.94 \pm 0.02^{a}$ & $8.96 \pm 0.12^{f}$ & $18.50 \pm 0.08^{h}$ & $0.54 \pm 0.01^{g}$ & $9.83 \pm 0.16^{c}$ & 41.60 & LCM \\
\hline & & & 30 & $2.28 \pm 0.17^{b}$ & $0.12 \pm 0.00^{b}$ & $0.87 \pm 0.13^{e}$ & $9.98 \pm 0.04^{\mathrm{g}}$ & $16.91 \pm 0.10^{\mathrm{e}}$ & $0.59 \pm 0.07^{g}$ & $8.60 \pm 0.09^{a}$ & 39.60 & CCM \\
\hline & & \multirow[t]{2}{*}{$\widehat{\partial}$} & 30 & $2.67 \pm 0.05^{c}$ & $0.13 \pm 0.00^{b}$ & $0.98 \pm 0.02^{f}$ & $7.45 \pm 0.37^{a}$ & $19.25 \pm 0.25^{1}$ & $0.27 \pm 0.02^{b c}$ & $13.02 \pm 0.06^{\mathrm{g}}$ & 44.01 & LCM \\
\hline & \multirow{5}{*}{ P. segnis } & & 30 & $2.47 \pm 0.16^{b c}$ & $0.10 \pm 0.01^{a}$ & $0.89 \pm 0.02^{\text {ef }}$ & $9.24 \pm 0.51^{\mathrm{fg}}$ & $17.56 \pm 0.38^{f g}$ & $0.27 \pm 0.03^{b c}$ & $9.35 \pm 0.31^{b c}$ & 40.14 & $\mathrm{CCM}$ \\
\hline & & \multirow{2}{*}{ q } & 30 & $2.98 \pm 0.15^{\mathrm{d}}$ & $0.15 \pm 0.01^{\mathrm{c}}$ & $0.67 \pm 0.04^{\mathrm{d}}$ & $8.84 \pm 0.20^{\mathrm{f}}$ & $19.60 \pm 0.38^{\mathrm{lm}}$ & $0.28 \pm 0.01^{\mathrm{bc}}$ & $13.88 \pm 0.09^{\mathrm{h}}$ & 46.69 & LCM \\
\hline & & & 30 & $3.14 \pm 0.07^{\mathrm{d}}$ & $0.13 \pm 0.02^{b c}$ & $0.56 \pm 0.03^{c}$ & $9.92 \pm 0.14^{\mathrm{g}}$ & $18.02 \pm 0.19^{\mathrm{g}}$ & $0.23 \pm 0.01^{\mathrm{a}}$ & $12.06 \pm 0.04^{\mathrm{ef}}$ & 44.34 & $\mathrm{CCM}$ \\
\hline & & \multirow{2}{*}{$\widehat{\sigma}$} & 30 & $2.43 \pm 0.08^{b c}$ & $0.12 \pm 0.01^{b}$ & $0.58 \pm 0.04^{\mathrm{c}}$ & $9.54 \pm 0.13^{\mathrm{g}}$ & $19.94 \pm 0.13^{\mathrm{m}}$ & $0.23 \pm 0.01^{\mathrm{a}}$ & $15.33 \pm 0.06^{\mathrm{k}}$ & 48.40 & LCM \\
\hline & & & 30 & $2.41 \pm 0.06^{\mathrm{bc}}$ & $0.11 \pm 0.01^{\mathrm{ab}}$ & $0.56 \pm 0.02^{\mathrm{c}}$ & $9.78 \pm 0.19^{\mathrm{g}}$ & $18.28 \pm 0.04^{\mathrm{gh}}$ & $0.25 \pm 0.01^{\mathrm{ab}}$ & $13.50 \pm 0.21^{\mathrm{h}}$ & 45.10 & CCM \\
\hline
\end{tabular}

Value in same column with different letters are significantly different $(\mathrm{P}<0.05) . \quad \overline{\mathrm{X}} \pm \mathrm{S}_{\mathrm{x}}:$ Standard deviation 


\section{References}

Ackman, R. G. \& McLeod, C. (1988). Total lipids and nutritionally important fatty acids of some Nova Scotia fish and shellfish food products. Canadian Institute Food Science and Technology Journal, 21, 390-398.

AOAC 2003. Official methods of analysis of AOAC international (17th ed.). Gaithersburg, MD, USA: Association of the Official Analytical Chemists (AOAC) International.

Ayas, D. \& Ozogul, Y. (2011a). The Chemical Composition and Meat Yield of Mature Blue Swimmer Crab (Portunus pelagicus, Linnaeus 1758) in Mersin Bay, Northeastern Mediterranean, Turkey. Advances in Food Sciences, 33(3), 179-184.

Ayas, D. \& Ozogul, Y. (2011). The Chemical Composition of Sexually Mature Blue Swimmer Crab (Portunus pelagicus, Linnaeus 1758) in the Mersin Bay. Journal of FisheriesSciences.com, 5(4), 308-316.

Bandarra, N.M., Batista, I., Nunes, M.L., Empis, J.M. \& Christie, W.W. (1997). Seasonal changes in lipid composition of sardine (Sardina pilchardus). Journal of Food Science, 62, 40-42.

Bell, M.V., Henderson, R.J. \& Sargent, J.R. (1985). Changes in the fatty acid composition of phospholipids from turbot (Scophthalmus maximus) in relation to dietary polyunsaturated fatty acid deficiencies. Comparative Biochemistry and Physiology, 81B, 193-198.

Bligh, E.G. \& Dyer, W.J., (1959). A rapid method of total lipid extraction and purification, Biochemistry and Cell Biology, 37(8), 911-917.

Burdge, G.C. \& Calder, P.C. (2005). Conversion of alpha-linolenic acid to longer-chain polyunsaturated fatty acids in human adults. Reproduction Nutrition Development, 45, 581597.

Brenna, J.T., Salem, N., Sinclair, A.J. \& Cunnane, S.C. (2009). Alpha-linolenic acid supplementation and conversion to n-3 long-chain polyunsaturated fatty acids in humans. Prostaglandins, Leukotrienes and Essential Fatty Acids, 80, (2-3), 85-91.

Chung, H.Y. (1999). Volatile components in crabmeats of Charybdis feriatus. Journal of Agricultural and Food Chemistry, 47, 2280-2287.

Devi, S.L. (1985). The fishery and biology of crabs of Kakinada region. Indian Journal of Fisheries, 32, 18-32.

Fischer, S. \& Wolff, M. (2006). Fisheries assessment of Callinectes arcuatus (Brachyura, Portunidae) in the Gulf of Nicoya, Costa Rica. Fisheries Research, 77, 301-311.

Fishstat plus. "Food and Agriculture Organization of the United Nations, Fisheries and Aquaculture Department", http://www.fao.org/fishery/statistics/software/en. (04.01.2010).

Gates, K.W., Parker, A.H., Bauer, D.L. \& Huang, Y. (1993). Storage changes of fresh and pasteurized blue crab meat in different types of packaging. Journal of Food Science, 58(2): 314-317.

Gökoğlu, N. \& Yerlikaya, P. (2003). Determination of proximate composition and mineral contents of blue crab (Callinectes sapidus) and swim crab (Portunus pelagicus) caught off the Gulf of Antalya. Food Chemistry, 80, 495-498.

Hall, D., Lee, S.Y. \& Meziane, T. (2006). Fatty acids as trophic tracer in an experimental estuarine food chain: Tracer transfer. Journal of Experimental Marine Biology and Ecology, $336,42-53$.

Ichihara, K., Shibahara, A., Yamamoto, K. \& Nakayama, T. (1996). An improved method for rapid analysis of the fatty acids of glycerolipids. Lipids, 31, 535-539.

King, I., Dorset, C. \& Monsen, E. R. (1990). Shellfish: Proximate composition, fatty acids, and sterols. Journal of American Dietetic Association, 90, 677-688.

Kuley, E., Özogul, F., Özogul, Y. \& Olgunoglu, I. A. (2008). Comparison of fatty acid and proximate compositions of the body and claw of male and female blue crabs (Callinectes 
sapidus) from different regions of the Mediterranean coast. International Journal of Food Sciences and Nutrition, 59(7-8), 573-580.

Luzia, L. A., Sampaio, G. R., Castellucci, C. M. N., \& Torres, E. A. F. S. (2003). The influence of season on the lipid profiles of five commercially important species of Brazilian fish. Food Chemistry, 83(1), 93-97.

McManus, A., Merga, M. \& Newton, W. (2011). Omega-3 fatty acids. What consumers need to know. Appetite, 57, 80-83.

Moustafa, E. K., Moharram, Y. G., El-Sokkary, I. \& Telb, A. I. (1987). Total mercury and its distribution in blue crab and deep water pink shrimp from Alexandra coast. Die Nahrung, 31, 773-776.

Naczk, M., Williams J., skonbern, K., Liyanapathirana, C. \& Shahidi, S. (2004). Compositional characteristics of green crab (Carcinus maenas). Food Chemistry, 88, 429434.

Razek, F.A.A. (1988). Some biological studies on the Egyptian crab Portunus pelagicus (Linnaeus, 1766). Acta Adriatica, 29, 133-144.

Reddy, N. R., Flick, G. J., Arganosa, G. C. \& Young, R. W. (1991). Composition and pesticide and herbicide residue analysis of fresh and 40-year old pasteurized blue crab (Callinectes sapidus) meat. Journal of Food Protection, 54(4), 298-301.

Shirai, N., Terayama, M. \& Takeda, H. (2002). Effect of season on the fatty acid composition and free amino acid content of the sardine Sardinops melanostictus. Comparative Biochemistry and Physiology Part B, 131, 387-397.

Siddiquie, P. J. A., Akbar, Z. \& Qasim, R. (1987). Biochemical composition and caloric values of three edible species of Portunidiae crabs from Karachi. Pakistan Journal of Science and Industrial Research, 30(2), 119-121.

Skonberg, D. I. \& Perkins, B. L. (2002). Nutrient composition of green crab (Carcinus maenas) leg meat and claw meat. Food Chemistry, 77, 401-404.

Styrishave, B. \& Andersen, O. (2000). Seasonal variations in hepatopancreas fatty acid profiles of two colour forms of shore crabs, Carcinus maenas. Marine Biology, 137, 415422.

Tzikas, Z., Amvrosiadis, I., Soultos, N. \& Georgakis, SP. (2007). Seasonal variation in the chemical composition and microbiological condition of Mediterranean Horse Mackerel (Trachurus mediterraneus) muscle from the North Aegean Sea (Greece). Food Control, 18, 251-257.

Wang, C., Harris, W. S., Chung, M., Lichtenstein, A. H., Balk, E. M., Kupelnick, B., Harmon, S.J., \& Lauet, J. (2006). n-3 fatty acids from fish or fish-oil supplements, but not a-linoleic acid, benefit cardiovascular disease outcomes in primary- and secondary-prevention studies. A systematic review. American Journal of Clinical Nutrition, 84, 5-17.

Zlatanos, S. \& Laskaridis, K. (2007). Seasonal variation in the fatty acid composition of three Mediterranean fish - sardine (Sardina pilchardus), anchovy (Engraulis encrasicholus) and picarel (Spicara smaris). Food Chemistry, 103,725-728. 